\section{Commercial Snap Bean Response to Fertilization with Broiler Litter}

\author{
James E. Brown ${ }^{1}$, Charles H. Gilliam ${ }^{2}$, and Ronald L. Shumack ${ }^{3}$ \\ Department of Horticulture and Alabama Agricultural Experiment Station, \\ Auburn University, AL 36849 \\ Daniel W. Porch ${ }^{4}$ \\ Alabama Cooperative Extension Service, Blount County Extension Office, \\ P.O. Box 610, Oneonta, AL 35121
}

Additional index words. plant nutrition, vegetable production, residual effect, foliar analysis, soil analysis, Phaseolus vulgaris

\begin{abstract}
Commercial snap bean (Phaseolus vulguris L.) yields in spring were similar when comparing a commercial fertilizer standard based on soil test recommendations to three application rates of broiler litter. Snap bean yields in the fall were higher on plots that received spring-applied broiler litter than on those receiving the commercial fertilizer standard in the fall. Increasing the application rate of broiler litter generally resulted in a linear yield response during both seasons.
\end{abstract}

Broiler litter is used as a nutrient source for commercial agronomic and horticulture crops (Link and Thomas, 1981). Increased yields have been reported on a variety of horticulture crops where broiler litter has been used as fertilizer (Liebhardt, 1976; Robertson and Wolford, 1970; Shortall and Liebhardt, 1975). Studies have been conducted to evaluate the effect of broiler litter application rate on sweet corn (Zea mays L.), watermelon [Citrullus lanatus (Thunb.) Matsum. and Nakai], and a variety of other vegetable crops (Robertson and Wolford, 1975; Sims, 1987; Sowell et al., 1963; Ware and Johnson, 1968). Based on these data, recommendations for using broiler litter can be made for several crops. We found no reports evaluating the use of a relatively high organic $\mathrm{N}$ source on a crop with low $\mathrm{N}$ requirements, such as snap beans. The objective of this research was to determine the effect of broiler litter on snap bean production, foliar nutrient content, and soil $\mathrm{pH}$ and nutrient concentrations on two soils in Alabama.

Soil samples were collected in Apr. 1989 at two locations: Sand Mountain Substation, Crossville, Ala. (Wynnville sandy loam), and the North Alabama Horticulture Substation in Cullman (Hartselle sandy loam). Plots were disked in late March and early April (27 Mar., Sand Mountain; 18 Apr., Cullman), and broiler litter was broadcast and then incorporated into the upper $1.5 \mathrm{~cm}$ of soil at 4.8, 9.5, and 19 t.ha ${ }^{-1}$. Commercial fertilizer was applied after planting as a standard treatment based on soil

Received for publication 20 Mar. 1992. Accepted forpublication Sept. 1992. Alabama Agricultural Experiment Station Journal Series no. 11-923246. The cost of publishing this paper was defrayed in part by the payment of page charges. Under postal regulations, this paper therefore must be hereby marked advertisement solely to indicate this fact.

'Associate Professor.

${ }^{2}$ Professor.

${ }^{3}$ Professor and Head.

"Assistant County Agent.

HorTSCIEnCE, Vol. 28(1), JANUARy 1993
Sept. (Cullman). Broiler litter was not applied to plots for the fall planting; however, commercial fertilizer was applied to the control plot at $\left(\mathrm{kg} \cdot \mathrm{ha}^{-1}\right) 72.8 \mathrm{~N}-32 \mathrm{P}-60 \mathrm{~K}$. Foliage at the early reproductive stage and soil samples were collected for chemical analysis. Beans at both locations were harvested on 2 Oct. 1989 using the procedures described for the spring test.

Spring snap bean yields ranged from 11.1 to $14.6 \mathrm{t} \cdot \mathrm{ha}^{-1}$ at Sand Mountain and from 5.5 to 7.3 t.ha ${ }^{-1}$ at Cullman. At both locations, applying broiler litter just before planting produced yields similar to those obtained by applying commercial fertilizer (Table 2).

Fall crop yields at Sand Mountain ranged from 8.1 to $12.2 \mathrm{t} \cdot \mathrm{ha}^{-1}$, while fall crop yields at Cullman ranged from 2.9 to $7.1 \mathrm{t} \cdot \mathrm{ha}^{-1}$. Applying broiler litter at 4.8, 9.5, and $19 \mathrm{t} \cdot \mathrm{ha}^{-1}$ increased yields $10 \%, 19 \%$, and 35\%, respectively, at Sand Mountain, compared with commercial fertilizer. Spring yields at Sand Mountain only and fall yields at both locations increased as broiler litter application rate increased. These data suggest that adequate nutrients were available from the broiler litter to support snap bean yield. Most of the previous and Mountain, and $86.8 \mathrm{~N}-38 \mathrm{P}-72 \mathrm{~K}$ at Cullman. Broiler litter was analyzed for $\mathrm{N}$ by a Kjeldahl method and for $\mathrm{Ca}, \mathrm{K}, \mathrm{Mg}, \mathrm{P}, \mathrm{Fe}$, $\mathrm{Mn}$, and $\mathrm{Zn}$ by inductively coupled argon plasma spectrophotometry (Ogg, 1960). A dry ash digestion procedure was used to prepare plant tissue samples to be analyzed. The Mehlich 1 extractant method was used for determining the $\mathrm{P}, \mathrm{K}, \mathrm{Ca}$, and $\mathrm{Mg}$ levels. Broiler litter nutrient concentrations were as follows: $2.8 \% \mathrm{~N}, 2.08 \% \mathrm{Ca}, 2.22 \% \mathrm{~K}, 0.33 \%$ $\mathrm{Mg}, 1.6 \%$ P, 1654 ppm Mn, and 437 ppm Zn. Rainfall was also recorded (Table 1).

In early May, plots were seeded with 'Strike' snap beans at eight to 10 seeds per $30.5 \mathrm{~cm}$ at Sand Mountain and four seeds per $30.5 \mathrm{~cm}$ at Cullman. Treatment plots consisted of six $6.1-\mathrm{m}$ rows, with $0.91 \mathrm{~m}$ between rows and a $1.5-\mathrm{m}$ alley between treatment plots. The statistical design was a randomized complete block with four replications. 2-Chloro- $N$-(2ethyl-6-methylphenyl)- $N$-(2-methoxy-1methylethyl)acetamide (dual,metolachlor) was applied postplant at a rate of $2.2 \mathrm{~kg}$ a.i./ha, and crops were cultivated as needed.

Foliar samples, including the trifoliate leaflets and petiole, in the early reproductive stage at $\approx 75 \%$ blossom from fully expanded new growth were collected at both locations in mid-June. Soil samples were collected on 21 June at Sand Mountain and 20 July 1989 at Cullman. Soil and foliar analyses were conducted by the Soil Testing Laboratory at Auburn Univ., Ala., using the techniques noted for broiler litter. Snap beans were harvested at both locations on 6 July. Yield data were taken from a $1.5-\mathrm{m}$ section of two interior rows of the six-row plot at Sand Mountain and from a 3.1-m section of two interior rows of a six-row plot at Cullman. Total weight was recorded.

After tilling the same treatment plots at both locations, 'Strike' snap beans were seeded in Fall 1989 by procedures similar to those described for the spring planting. Planting dates were 29 Aug. (Sand Mountain) and 6
Table 1. Monthly and 30-year average rainfall in northern Alabama experimental areas during 1989.

\begin{tabular}{lccc}
\hline & \multicolumn{3}{c}{ Rainfall (mm) } \\
\cline { 2 - 4 } & $\begin{array}{c}\text { Sand } \\
\text { Mountain }\end{array}$ & Cullman & $\begin{array}{c}30-\mathrm{yr} \\
\text { avg }\end{array}$ \\
\hline April & 83 & 59 & 133 \\
May & 84 & 102 & 113 \\
June & 207 & 291 & 94 \\
July & 227 & 325 & 100 \\
August & 44 & 85 & 81 \\
September & 223 & 123 & 116 \\
October & 56 & 80 & 72 \\
Total & 924 & 1065 & 709 \\
\hline
\end{tabular}

Table 2. Effect of broiler litter (BL) rate and commercial fertilizer (CF) on marketable snap bean yield in two Alabama locations.

\begin{tabular}{|c|c|c|}
\hline \multirow{2}{*}{$\begin{array}{l}\text { Crop and } \\
\text { fertilizer } \\
\left(\mathrm{t} \cdot \mathrm{ha}^{-1}\right)\end{array}$} & \multicolumn{2}{|c|}{ Yield (t.ha ${ }^{-1}$ ) } \\
\hline & $\begin{array}{c}\text { Sand } \\
\text { Mountain }\end{array}$ & Cullmar \\
\hline \multicolumn{3}{|l|}{ Spring } \\
\hline $\mathrm{CF}^{2}$ & 11.1 & 7.3 \\
\hline \multicolumn{3}{|l|}{$\mathrm{BL}$} \\
\hline 4.8 & 11.3 & 6.2 \\
\hline 9.5 & 11.2 & 5.5 \\
\hline 19.0 & 14.6 & 6.1 \\
\hline \multicolumn{3}{|l|}{ Significance } \\
\hline CF vs. BL & NS & NS \\
\hline $\mathrm{BL}$ rate linear & $* *$ & NS \\
\hline \multicolumn{3}{|l|}{ Fall } \\
\hline $\mathrm{CF}$ & 8.1 & 3.8 \\
\hline \multicolumn{3}{|l|}{$\mathrm{BL}$} \\
\hline 4.8 & 8.9 & 2.9 \\
\hline 9.5 & 9.9 & 3.9 \\
\hline 19.0 & 12.2 & 7.1 \\
\hline \multicolumn{3}{|l|}{ Significance } \\
\hline CF vs. BL & $*$ & NS \\
\hline $\mathrm{BL}$ rate linear & $*$ & $*$ \\
\hline
\end{tabular}

${ }^{2} \mathrm{CF}$ : Sand Mountain for spring and fall $\left(\mathrm{kg} \cdot \mathrm{ha}^{-1}\right)=$ $72.8 \mathrm{~N}-32 \mathrm{P}-60 \mathrm{~K}$; Cullman for spring $\left(\mathrm{kg} \mathrm{ha}^{-1}\right)=$ $86.8 \mathrm{~N}-38 \mathrm{P}-72 \mathrm{~K}$, and for fall $=72.8 \mathrm{~N}-32 \mathrm{P}-60 \mathrm{~K}$. ${ }_{* s, *, * *}$ Nonsignificant or significant at $P=0.05$ or 0.01 , respectively. 
work has used broiler litter as an organic $\mathrm{N}$ source to evaluate crops with high $\mathrm{N}$ requirements (Albregts and Howard, 1981; Robertson and Wolford, 1975).

Mean foliar N content for Sand Mountain spring-planted beans ranged from $3.7 \%$ to 4.8\%. Foliar $\mathrm{N}, \mathrm{Ca}, \mathrm{K}, \mathrm{Mg}, \mathrm{P}$, and $\mathrm{Mn}$ responded linearly to increasing broiler litter rates (Table 3). Foliar nutrient levels were similar for commercial fertilizer and broiler litter except for $\mathrm{K}$ and $\mathrm{P}$, which, on average, were lower with commercial fertilizer. Increasing broiler litter applicationrate increased leaf nutrient concentration, except for $\mathrm{Fe}$ and $\mathrm{Zn}$.

For the fall crop, mean foliar $\mathrm{N}$ content ranged from $4.3 \%$ to $4.9 \%$. Although not compared statistically, applying broiler litter at $4.8 \mathrm{t} \cdot \mathrm{ha}^{-1}$ in the spring resulted in higher foliar $\mathrm{N}$ in the fall crop $(4.3 \% \mathrm{~N})$ than in the spring crop $(3.7 \% \mathrm{~N})$. This difference indicates that $\mathrm{N}$ was becoming available long after the spring crop was harvested. Control plants receiving a fall application of commercial fertilizer contained higher levels of all nutrients, except $\mathrm{P}$, than plants grown with broiler litter where commercial fertilizer had been applied only in spring (Table 3).

Foliar $\mathrm{N}$ levels for spring-planted snap beans grown at Cullman ranged from $3.8 \%$ to $4.3 \%$. Commercial fertilizer produced higher foliar N levels than broiler litter (Table 4). Phosphorous, $\mathrm{Fe}$, and $\mathrm{Mn}$ concentrations were higher when broiler litter was the fertilizer source, and those for P and Fe increased as the application rate increased.

Data for fall-planted Cullman beans were consistent with data for Sand Mountain beans in that the commercial fertilizer resulted in higher foliar $\mathrm{N}$ levels than the broiler litter. Concentrations of foliar $\mathrm{P}$ and $\mathrm{Fe}$ were higher with broiler litter than with commercial fertilizer, but only Fe concentrations increased with increasing broiler litter application rates (Table 4).

Fertilizer source influenced soil $\mathrm{pH}$ of the Wynnville sandy loam soil at Sand Mountain. Soil $\mathrm{pH}$ was lower with commercial fertilizer than with broiler litter (Table 5). Soil K levels were lower with broiler litter than with commercial fertilizer. At Cullman, soil $\mathrm{P}$ concentration increased as the broiler litter application rate increased, a result that agrees with results reported by Ware and Johnson (1968) for the Hartselle sandy loam soil. Soil $\mathrm{pH}$ was also lower at Cullman (Hartselle sandy loam) when commercial fertilizer was applied, these data agree with results from work with corn $(Z$. mays) (Liebhardt, 1976).

In summary, broiler litter provided adequate nutrients to produce snap beans. Broiler litter applied at $4.8 \mathrm{t} \cdot \mathrm{ha}^{-1}$ was as effective as the commercial fertilizer at both locations. These results indicate that crops with low $\mathrm{N}$ requirements, such as snap beans, can be produced effectively with relatively low rates of broiler litter. When snap beans were grown as a double (fall) crop following the spring crop on the same soil, yields produced with only the residual broiler litter were similar to those produced with the commercial fertilizer. Also,
Table 3. Effect of broiler litter (BL) and commercial fertilizer (CF) rate on foliar nutrient content of snap beans grown in a Wynnville sandy loam soil at Sand Mountain, Ala.

\begin{tabular}{|c|c|c|c|c|c|c|c|c|}
\hline \multirow{2}{*}{$\begin{array}{l}\text { Crop and } \\
\text { fertilizer }\left(\mathrm{t} \cdot \mathrm{ha}^{-1}\right)\end{array}$} & $\mathbf{N}$ & $\mathrm{Ca}$ & $\mathbf{K}$ & $\mathrm{Mg}$ & $\mathrm{P}$ & $\mathrm{Fe}$ & $\mathrm{Mn}$ & $\mathrm{Zn}$ \\
\hline & \multicolumn{5}{|c|}{$\%$} & \multicolumn{3}{|c|}{ ppm } \\
\hline \multicolumn{9}{|l|}{ Spring } \\
\hline $\mathrm{CF}^{\mathrm{z}}$ & 4.3 & 1.1 & 2.0 & 0.24 & 0.37 & 290 & 33 & 39 \\
\hline \multicolumn{9}{|l|}{$\mathrm{BL}$} \\
\hline 4.8 & 3.7 & 1.0 & 1.9 & 0.23 & 0.37 & 255 & 32 & 43 \\
\hline 9.5 & 4.3 & 1.1 & 2.2 & 0.25 & 0.44 & 240 & 35 & 44 \\
\hline 19.0 & 4.8 & 1.3 & 2.5 & 0.26 & 0.46 & 267 & 37 & 47 \\
\hline \multicolumn{9}{|l|}{ Significance } \\
\hline CF vs. BL & NS & NS & $*$ & NS & * & NS & NS & NS \\
\hline BL rate linear & $* *$ & * & ** & * & ** & NS & $*$ & NS \\
\hline \multicolumn{9}{|l|}{ Fall } \\
\hline $\mathrm{CF}$ & 4.9 & 1.6 & 1.9 & 0.35 & 0.41 & 221 & 158 & 26 \\
\hline \multicolumn{9}{|l|}{ BL } \\
\hline 4.8 & 4.3 & 1.3 & 1.3 & 0.32 & 0.36 & 164 & 55 & 10 \\
\hline 9.5 & 4.3 & 1.3 & 1.6 & 0.29 & 0.38 & 152 & 52 & 11 \\
\hline 19.0 & 4.4 & 1.3 & $1.7^{\circ}$ & 0.29 & 0.36 & 153 & 52 & 16 \\
\hline \multicolumn{9}{|l|}{ Significance } \\
\hline CF vs. BL & $* *$ & $* *$ & *** & ** & NS & ** & $* *$ & $*$ \\
\hline BL rate linear & NS & NS & $* *$ & NS & NS & NS & NS & NS \\
\hline
\end{tabular}

${ }^{2} \mathrm{CF}$ : Sand Mountain for spring and fall $\left(\mathrm{kg}^{\mathrm{k}} \mathrm{ha}^{-1}\right)=72.8 \mathrm{~N}-32 \mathrm{P}-60 \mathrm{~K}$

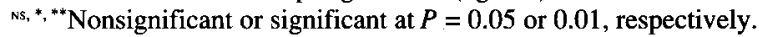

Table 4. Effects of broiler litter (BL) and commercial fertilizer (CF) rate on foliar nutrient content of snap beans grown in a Hartselle sandy loam soil at Cullman, Ala.

\begin{tabular}{|c|c|c|c|c|c|c|c|c|}
\hline \multirow{2}{*}{$\begin{array}{l}\text { Crop and } \\
\left.\text { fertilizer (t.ha }{ }^{-1}\right)\end{array}$} & $\mathbf{N}$ & $\mathrm{Ca}$ & $\mathrm{K}$ & $\mathrm{Mg}$ & $\mathrm{P}$ & $\mathrm{Fe}$ & $\mathbf{M n}$ & $\mathrm{Zn}$ \\
\hline & & & $\%$ & & & \multicolumn{3}{|c|}{ ppm } \\
\hline \multicolumn{9}{|l|}{ Spring } \\
\hline $\mathrm{CF}^{2}$ & 4.3 & 1.5 & 0.27 & 0.29 & 0.30 & 227 & 121 & 27 \\
\hline \multicolumn{9}{|l|}{$\mathrm{BL}$} \\
\hline 4.8 & 3.9 & 1.6 & 0.31 & 0.29 & 0.35 & 313 & 281 & 26 \\
\hline 9.5 & 3.8 & 1.9 & 0.33 & 0.32 & 0.36 & 337 & 203 & 21 \\
\hline 19.0 & 4.2 & 1.9 & 0.35 & 0.32 & 0.38 & 347 & 214 & 30 \\
\hline \multicolumn{9}{|l|}{ Significance } \\
\hline CF vs. BL & * & NS & NS & NS & $* *$ & * & ** & NS \\
\hline BL rate linear & NS & NS & NS & NS & $*$ & $*$ & NS & NS \\
\hline \multicolumn{9}{|l|}{ Fall } \\
\hline $\mathrm{CF}$ & 5.1 & 1.6 & 0.33 & 0.37 & 0.35 & 187 & 180 & 35 \\
\hline \multicolumn{9}{|l|}{ BL } \\
\hline 4.8 & 4.5 & 1.7 & 0.31 & 0.33 & 0.38 & 208 & 80 & 25 \\
\hline 9.5 & 4.4 & 1.9 & 0.32 & 0.36 & 0.38 & 231 & 79 & 25 \\
\hline 19.0 & 4.7 & 1.8 & 0.30 & 0.34 & 0.39 & 236 & 86 & 23 \\
\hline \multicolumn{9}{|l|}{ Significance } \\
\hline CF vs. BL & ** & NS & NS & NS & $*$ & ** & $* *$ & ** \\
\hline BL rate linear & NS & NS & NS & NS & NS & $*$ & NS & NS \\
\hline
\end{tabular}

${ }^{{ }^{2} \mathrm{CF}}$ : Cullman for spring $\left(\mathrm{kg}^{\circ} \cdot \mathrm{ha}^{-1}\right)=86.8 \mathrm{~N}-38 \mathrm{P}-72 \mathrm{~K}$; fall $=72.8 \mathrm{~N}-32 \mathrm{P}-60 \mathrm{~K}$.

Ns, *, "*N Nonsignificant or significant at $P=0.05$ or 0.01 , respectively.

Table 5. Effect of broiler litter (BL) and commercial fertilizer (CF) rate on soil analysis at two locations.

\begin{tabular}{|c|c|c|c|c|c|}
\hline $\begin{array}{l}\text { Crop and } \\
\text { fertilizer }\left(\mathrm{t} \cdot \mathrm{ha}^{-1}\right)\end{array}$ & $\mathrm{pH}$ & \multicolumn{3}{|c|}{$\left(\mathrm{kg} \cdot \mathrm{ha}^{-1}\right)$} & $\mathrm{Ca}$ \\
\hline \multicolumn{6}{|c|}{ Sand Mountain, Ala. (Wynnville sandy loam) } \\
\hline Initial sample & 5.5 & 159 & 370 & 61 & 590 \\
\hline $\mathrm{CF}^{\mathrm{z}}$ & 5.8 & 255 & 387 & 195 & 983 \\
\hline \multicolumn{6}{|l|}{$\mathrm{BL}$} \\
\hline 4.8 & 6.3 & 210 & 330 & 222 & 938 \\
\hline 9.5 & 6.4 & 222 & 349 & 273 & 1148 \\
\hline 19.0 & 6.5 & 234 & 345 & 255 & 1165 \\
\hline \multicolumn{6}{|l|}{ Significance } \\
\hline CF vs. BL & ** & NS & ** & NS & NS \\
\hline BL rate linear & NS & NS & NS & NS & NS \\
\hline \multicolumn{6}{|c|}{ Cullman, Ala. (Hartselle sandy loam) } \\
\hline Initial sample & 6.4 & 27 & 109 & 116 & 920 \\
\hline $\mathrm{CF}$ & 6.1 & 56 & 137 & 129 & 893 \\
\hline \multicolumn{6}{|l|}{$\mathrm{BL}$} \\
\hline 4.8 & 6.4 & 60 & 112 & 157 & 834 \\
\hline 9.5 & 6.4 & 74 & 143 & 169 & 955 \\
\hline 19.0 & 6.3 & 119 & 143 & 166 & 960 \\
\hline \multicolumn{6}{|l|}{ Significance } \\
\hline CF vs. BL & * & $*$ & NS & * & NS \\
\hline $\mathrm{BL}$ rate linear & NS & ** & * & NS & NS \\
\hline
\end{tabular}

${ }^{2} \mathrm{CF}$ : Sand Mountain for spring and fall $\left(\mathrm{kg} \cdot \mathrm{ha}^{-1}\right)=72.8 \mathrm{~N}-32 \mathrm{P}-60 \mathrm{~K}$; Cullman for spring $=86.8 \mathrm{~N}-38 \mathrm{P}-72 \mathrm{~K}$, and for fall $=72.8 \mathrm{~N}-32 \mathrm{P}-60 \mathrm{~K}$.

ws, ${ }^{*},{ }^{* *}$ Nonsignificant or significant at $P=0.05$ or 0.01 , respectively. 
litter applied at $19 \mathrm{t} \cdot \mathrm{ha}^{-1}$ did not lower yields of this low-N-requirement plant.

\section{Literature Cited}

Albregts, E.E. and C.M. Howard. 1981. Effects of poultry manure on strawberry fruiting response, soil nutrient changes, and leaching. J. Amer. Soc. Hort. Sci. 106:295-298.

Liebhardt, W.C. 1976. Nutrient concentration of corn as affected by poultry manure. Commun. Soil Sci. Plant Anal. 7:175-188.

Link, J.G. and C.F. Thomas. 1981. The value and use of poultry manure as a fertilizer. Soil Fertilizer Fact Sheet, Alabama Coop. Ext. Serv. Auburn Univ., Circ. AWR-244.

Ogg, C.L. 1960. Chemical analysis methods. J. Assn. Offic. Anal. Chemists 43:689-693.

Robertson, L.S. and J. Wolford. 1970. The effect of application rate of chicken manure on the yield of corn. Mich. Agr. Expt. Sta. Res. Rpt. 117:1015.

Robertson, L.S. and J.H. Wolford. 1975. Corn grain yields in soil fertility levels as affected by five rates of poultry manure. Mich. Agr. Expt. Sta. Res. Rpt. 269:21-28.
Sims, J.T. 1987. Agronomic evaluation of poultry manure as a nitrogen source for conventional and no-tillage corn. Agron. J. 79:563-570.

Shortall, J.G. and W.C. Liebhardt. 1975. Yield and growth of corn as affected by poultry manure. J. Environ. Qual. 4:186-191.

Sowell, W.F., J.C. Lowery, and J.R. Hubbard. 1963. The value and use of poultry manure. Ala. Coop. Ext. Serv. Circ. 634:1-5.

Ware, L.M. and W.A. Johnson. 1968. Poultry manure for vegetable crops-Effects and value. Ala. Agr. Expt. Sta. Bul. 1968:3-31. 